ПРИРОДНИЧІ НАУКИ. ТЕХНОЛОГІЇ

УДК 37.015.31:57.081.1

DOI: 10.37026/2520-6427-2019-100-4-116-118
Світлана ГРЕБІНЬ,

кандидат філософських наук,

доиент кафедри дидактики та методик

навчання природничо-математичних дисичилін

Запорізького ОІППО

Ірина ВАРЛАМОВА,

доктор економічних наук,

професор кафедри обліку та оподаткування

Запорізького національного університету

\title{
ВИВЧЕННЯ ГЛОБАЛЬНИХ ПРОБЛЕМ ЛЮДСТВА У ФОРМУВАННІ ЕКОЛОГІЧНӦ̈ КОМПЕТЕНТНОСТІ УЧНІВ
}

У статті акиентується увага на важливості отримання школярами комплексних знань, які зачіпають глобальні проблеми сучасності та шляхи їх вирішення. На нинішньому етапі розвитку цивілізаиії загострилися проблеми, щзо стосуються життевих інтересів як кожної окремої людини, так і иілих народів та всього людства загалом. Розв'язання иих проблем вимагає колективних зусиль значної кількості людей. Майбутнє нашої планети залежить від високого рівня наукових знань, нового типу мислення й екологічних свідомості, культури та світогляду підростаючого покоління. Якісне формування екологічної компетентності школярів неможливе без надання їм елементарних знань, шо стосуються глобальних проблем сучасності та шляхів їх вирішення. Вказана філософсько-природнича проблематика $\epsilon$ важливим ключем до збереження життя на нашій планеті та подальшого розвитку людства.

Ключові слова: глобальні проблеми сучасності, екологічна компетентність, екологічна свідомість, екологічний світогляд, екологічна культура.

В статье акцентируется внимание на важности получения школьниками комплексных знаний, затрагиваюших глобальные проблемы современности и пути их решения. На нынешнем этапе развития ияивилизации обострились проблемы, затрагивающие жизненные интересы как каждого отдельного человека, так и иельх народов и всего человечества в иелом. Решение этих проблем требует коллективныхх усилий многих людей. Будущее нашей планеть зависит от высокого уровня научных знаний, нового типа мышиления и экологического сознания, культуры и мировоззрения подрастающего поколения. Качественное формирование экологической компетент- ности школьников невозможно без получения ими элементарных знаний, касающихся глобальных проблем современности и путей их решения. Указанная философско-естественнонаучная проблематика является важныл ключом к сохранению жизни на нашей планете и дальнейшему развитию человечества.

Ключевые слова: глобальные проблемы современности, экологическая компетентность, экологическое сознание, экологическое мировоззрение, экологическая культура.

The article focuses on the importance of obtaining complex knowledge by schoolchildren, affecting the global problems of modernity and ways to solve them. At the present stage of the development of civilization, problems affecting the vital interests of both individual people and entire nations and the whole of humanity as a whole have become aggravated. Solving these problems requires the collective efforts of many people. Global warming and damage from human activities, meteoric and asteroid threats, the spread of viral and infectious diseases, overpopulation of the planet, lack of food, the depletion of mineral reserves, the search for alternative energy sources, etc. for their solution require complex knowledge from people, new scientific discoveries and modern technology.

The constant attention of mankind, the deepening of scientific knowledge and the involvement of the younger generation to these problems will help save life on planet Earth. Consumer attitude to our planet is in the past. The new Ukrainian education system provides for the provision of basic knowledge of this subject to our children, defines one of the tasks - the formation of environmental competence and uses a humanistic approach to learning, within which the problem of a humane attitude to our planet as a whole is relevant. 
It is impossible to form a high-quality environmental competence of schoolchildren without their obtaining knowledge on the global problems of modern times and ways to solve them. This philosophical and natural science problematic is an important key to the preservation and further development of our civilization. The future of our planet depends on a high level of scientific knowledge, a new type of thinking, ecological consciousness, culture and worldview of the younger generation.

Key words: global problems of the present, ecological competence, ecological consciousness, ecological world outlook, ecological culture.

Постановка проблеми. На сучасному етапі розвитку цивілізації загострилися проблеми, що мають планетарний характер. Ці проблеми зачіпають життєві інтереси як кожної окремої людини, так і цілих народів та всього людства загалом. Їх розв'язання вимагає колективних зусиль значної кількості людей. Глобальне потепління та шкода від господарської діяльності людини, метеоритна та астероїдна загроза, поширення вірусних та інфекційних захворювань, перенаселення планети, нестача продуктів харчування, виснаження запасів корисних копалин, пошук альтернативних джерел енергії тощо - усе це вимагає від людини комплексних знань, нових наукових відкриттів та сучасних технологій. Постійна увага людства, поглиблення наукових знань та залучення молодого покоління до вказаних проблем допоможуть зберегти життя на планеті Земля. Споживацьке відношення до нашої планети залишилося в минулому. Нова українська система освіти одним із ключових завдань визначає формування екологічної компетентності та використання гуманістичного підходу до навчання, у межах яких актуальною $є$ і проблема гуманного відношення до планети загалом. Доцільним щодо цього буде надання елементарних знань із означеної тематики дітям.

Аналіз наукових досліджень та публікацій. На сьогодні маємо чимало досліджень та наукових фактів, які підтверджують актуальність даної філософсько-природничої проблематики та вказують на необхідність підготовки майбутнього покоління до пошуку шляхів та засобів вирішення цих питань.

Дослідженням глобальних проблем сучасності та ïx філософськими аспектами займалися А. В. Арістова, В. Х. Арутюнов, В. П. Капітон, М. М. Книш, А. М. Маковецький; соціально-історичний аналіз цих проблем здійснив Е. А. Афонін; питання глобалістичної свідомості, політичної культури, різних політичних та ідеологічних аспектів щодо розв'язання глобальних проблем сучасності висвітлили Р. М. Колісніченко, В. О. Корнієнко, а у сфері державного та публічного управління - Т. В. Смельянова та І. В. Сухара. Аспекти економічної та європейської інтеграції розкрили П. Ю. Буряк, О. Г. Гупало, Г. П. Задорожня, Д. Г. Лук'яненко, О. О. Пономаренко, Т. В. Новікова, М. А. Сіроштан; екологічні детермінанти міжнародних економічних відносин досліджувала Н. В. Резнікова; методологічну роль гуманістично-ноосферної концепції в розв'язанні глобальних проблем сучасності вивчав В. С. Карпенко; питаннями соціального проєктування в контексті розв'язання вказаних проблем займався В. І. Пустовойт; аспекти глобальної продовольчої проблеми та імперативи її вирішення в сучасних умовах аналізувала Н. В. Стежко.
Як бачимо, аналіз питань, пов'язаних із глобальними проблемами сучасності, представлений широко та досить різнобічно, що свідчить про їх актуальність та повернення сучасної науки в бік гуманного відношення до нашої планети.

Органічним продовженням цих досліджень $є$ розкриття питань щодо формування екологічної компетентності молодого та підростаючого покоління, що значно полегшило б розв'язання глобальних проблем сучасності в майбутньому. Формуванню екологічної компетентності студентів присвятили свої роботи Н. В. Баюрко, В. М. Боголюбов, О. Л. Герасимчук, С. М. Грищенко, О. В. Гуренкова, С. І. Ключка, Я. О. Логвінова, Т. Ф. Лукашенко, Л. Б. Лук'янова, С. М. Лутковська, Н. Ю. Олійник, М. В. Осадча, А. П. Сваричевська, Н. І. Стрижак, Л. М. Титаренко, А. Л. Хрипунова, Н. М. Черновол; питання формування екологічної компетентності дітей дошкільного віку вивчала 3. П. Плохій; різноманітні аспекти формування екологічної компетентності школярів Н. В. Куриленко, Г. Г. Найдьонова, Н. А. Пустовіт; оцінювання сформованості екологічних компетентностей - В. П. Карпенко, I. І. Мостов'як, Т. М. Пушкарьова-Безділь; аспекти взаємодії сім'ї і школи у формуванні екологічної компетентності школярів висвітлила Л. Д. Руденко.

Мета статті - розкрити питання про неможливість якісного формування екологічної компетентності школярів без надання елементарних знань, які відображають глобальні проблеми сучасності та шляхи їх вирішення. Ця філософсько-природнича тематика $\epsilon$ важливим ключем до збереження та подальшого розвитку цивілізації. Майбутнє нашої планети залежить від високого рівня наукових знань, нового типу мислення та екологічних свідомості, культури і світогляду підростаючого покоління.

Виклад основного матеріалу. Одним із перших кроків щодо визначення глобальних проблем сучасності та передвісником розгляду цього питання вченими на світовому рівні була теорія про ноосферу видатного вченого В. Вернадського, яка з'явилася ще у 30-х роках XX століття. Згідно з цією теорією людина не $\epsilon$ самодостатньою живою істотою, яка живе за своїми особливими законами, а частина природи, що співіснує всередині неї [4]. Біосфера Землі «в результаті техногенної діяльності людини» істотно змінюється та стає ноосферою - «сферою розуму», що торкнеться все більшої частини планети - «від глибоких ії надр до найвищих шарів атмосфери» [1]. Життя на всі планети заноситься з космосу, його «зародки» за сприятливих умов можуть еволюціонувати, вдосконалюватися та розповсюджуватися далі в космосі на інші планети Всесвіту [1]. На це життя впливають як космічні фактори (наприклад, випромінювання сонця), так і людина в результаті своєї господарської діяльності.

Наступним кроком, який свідчить про визнання існування сучасних глобальних проблем та бажання людей їх розв'язати, є заснування у 1968 році в Женеві (Швейцарія) римським економістом та підприємцем, доктором Ауреріо Печчеї Римського клубу. Ця неприбуткова громадська організація нараховувала у своєму складі 30 незалежних експертів із 10 країн, які мали оцінювати довгострокові наслідки існуючих глобальних проблем та перспективи розвитку людства. Сьогодення вказує на актуальність існування цього клубу, адже туди входить уже близько 100 осіб із 30 країн світу, що об'єднані почуттям гуманізму та турботою про долю людства. 
Це - видатні вчені, мислителі, менеджери, педагоги, представники освіти та ін. Тривалий час членом Римського клубу був і видатний український економіст та науковець Богдан Гаврилишин.

Римський клуб на сучасному етапі став своєрідним каталізатором вирішення глобальних проблем людства та стимулятором суспільної дискусії щодо знаходження ефективних заходів поліпшення перспектив майбутнього. Його члени на основі комплексного та перспективного аналізу виявляють найбільш важливі проблеми, які визначають майбутнє людства, розробляють практичні рішення щодо наявних проблем та займаються оцінкою альтернативних сценаріїв розвитку майбутнього [6].

До початку XXI століття сучасною наукою запропоновано розглянути низку проблем (космічних, екологічних, воєнних, медичних, соціальних, демографічних, продовольчих тощо), розв'язання яких сприятиме виживанню людства на нашій планеті. Існує ряд класифікацій цих проблем, авторами найбільш відомих 3 них є норвезький соціолог И. Галтунго Му та польський політолог А. Воднар.

Для прикладу детальніше розглянемо лише одну глобальну проблему людства та наслідки від неї - це проблема кліматичних змін на планеті, що пов'язана 3 глобальним потеплінням та посилюється техногенними причинами, зокрема викидами парникових газів. Цей процес став реальною загрозою існуванню людства в майбутньому.

Сучасні вчені визначають, що «розігрівання нижніх шарів атмосфери», так званий парниковий ефект, який виникає в результаті «поглинання відбитого теплового випромінювання поверхні Землі молекулами водяної пари, вуглекислого газу, метану, хлорфторвуглеців і деяких інших газів, призведе до значного потепління» [2]. Цей процес буде супроводжуватися «таненням полярного льоду, підйомом рівня Світового океану, затопленням густонаселених приморських низовин і цілих острівних держав, скороченням кількості опадів влітку (на $15-20 \%$ ) в основних сільськогосподарських районах та їх опустелюванням від середнього заходу Америки до Середземного моря i Західної Австралії» [2].

У 1990 році відбувся Міжнародний пленум щодо кліматичних змін, де була представлена доповідь першої робочої групи про результати дослідження 170 авторитетних фахівців із 25 країн світу, в якій вказувалося на істотне підсилення показників, що свідчать про глобальне потепління на нашій планеті. Ще 200 видатних учених були залучені до рецензування цієї доповіді. Усі вони одностайно висловили думку про те, що «парниковий ефект уже дав потепління на 0,3 $-0,6^{\circ} \mathrm{C}$ (у середньому $-0,5^{\circ} \mathrm{C}$ ) 3 кінця XIX століття. Подвоєння вмісту СО2 в атмосфері відбудеться до 2035 року. Відповідно глобальне потепління становитиме від $1,5^{\circ}$ до $4,5^{\circ} \mathrm{C}$, швидше за все це буде близько $2,5^{\circ} \mathrm{C}$. До цього часу очікується підйом рівня моря від 8 до 29 см (у середньому - близько 20 см) та до 65 см відповідно до 2100 року. На великих просторах Свразії та Північної Америки, включаючи основні житниці, встановиться літній сухий клімат» [2].

Аби запобігти «згубним наслідкам кліматичних змін, передбачається зниження викидів двоокису вуглецю, оксидів азоту і хлорфторвуглеців на $60 \%$, а метану на 20 \%. Ці рекомендації, по суті, свідчать про крутий поворот адаптивної стратегії людини, адже раніше людина боролася з холодом, тепер починає боротися з теплом. Раніше вона розбудовувала свою діяльність, пристосовуючись до змін середовища, а тепер перебудовує іiі задля збереження статусу-кво» [2].

Як бачимо із наведеного прикладу, із плином часу означена проблема, як і деякі інші, продовжуватиме загострюватися. Для іiі розв'язання в найближчому майбутньому знадобляться талановиті вчені та кваліфіковані фахівці, їх неординарні рішення та результати сучасних досліджень. Турбуватися про цей потенціал та формувати своє майбутнє людство має вже сьогодні. Наші діти є тим потенціалом, який повинен бути готовим до вирішення глобальних проблем сучасності.

Концепція екологічної освіти в Україні вказує на необхідність надання екологічних знань та формування в дітей, починаючи з молодшого віку (дошкільнят та молодших школярів), екологічної свідомості, мислення та світогляду, екологічної етики та культури з метою збереження життя на планеті. Закладу загальної середньої освіти відводиться провідна та найважливіша роль щодо екологічної освіти й виховання учнівської молоді $[3 ; 5]$. Ця концепція була представлена ще у 2002 році. Із тих пір пройшло чимало часу, зроблені нові дослідження, отримано нові результати та дані, тому це питання потребує грунтовного переосмислення.

Висновки. Отже, розв'язання глобальних проблем людства $\epsilon$ важливим напрямом збереження та розвитку цивілізації. Надання елементарних знань iз цієї філософсько-природничої тематики в межах гуманістичного підходу до навчання $є$ необхідною складовою формування екологічної компетентності дітей, починаючи 3 молодшого шкільного віку. Майбутнє нашої планети - у руках підростаючого покоління і залежить від наявності в нього ексцентричного, нового типу мислення, високого рівня екологічних знань, свідомості, світогляду та культури.

\section{СПИСОК ВИКОРИСТАНОЇ ЛІТЕРАТУРИ}

1. В. I. Вернадський та його вчення про біосферу i ноосферу. URL: https://buklib.net/books/33729/ (дата звернення: 26.06.2019).

2. Глобальные проблемы человечества. URL: https://center-yf.ru/data/stat/Globalnye-problemychelovechestva.php (дата звернення: 26.06.2019).

3. Іванова Т. В. Екологічна освіта як базова складова екологічної політики держави / Т. В. Іванова // Вісник Національного авіаційного університету. - 2017. - № 11. - (Серія «Педагогіка, психологія»). URL: http://jrnl.nau.edu.ua/index.php/VisnikPP/article/ view/12553 (дата звернення: 26.06.2019).

4. Ноосфера Вернадського В. I. Навчальні матеріали онлайн. URL: https://pidruchniki.com/83620/ menedzhment/noosfera_vernadskogo (дата звернення: 26.06.2019).

5. Про концепцію екологічної освіти в Україні. URL: http://consultant.parus.ua/?doc $=01 \mathrm{E} 1 \mathrm{O} 32 \mathrm{CC} 0$ (дата звернення: 26.06.2019).

6. Римський клуб : матеріали із Вікіпедії. URL: https://uk.wikipedia.org/wiki/\%D0\%A0\%D0\%B8\%D0 $\% \mathrm{BC} \% \mathrm{D} 1 \% 81 \% \mathrm{D} 1 \% 8 \mathrm{C} \% \mathrm{D} 0 \% \mathrm{BA} \% \mathrm{D} 0 \% \mathrm{~B} 8 \% \mathrm{D} 0 \% \mathrm{~B}$ $9 \% \mathrm{D} 0 \% \mathrm{BA} \% \mathrm{D} 0 \% \mathrm{BB} \% \mathrm{D} 1 \% 83 \% \mathrm{D} 0 \% \mathrm{~B} 1$ (дата звернення: 26.06.2019).

Дата надходження до редакиії: 09.09.2019 p. 